\title{
The Relation Between Monocyte to High-Density Lipoprotein Cholesterol Ratio and Short Term Outcome in Patients with Acute ST Segment Elevation Myocardial Infarction Undergoing Primary Percutaneous Coronary Intervention
}

\author{
AHMED I. EL-SHALL, M.B.B.Ch.; SEHAM F. BADR, M.D.; HATEM F. EL-SOKKARY, M.D. and \\ AHMED F. ALARAG, M.D.
}

The Department of Cardiology, Faculty of Medicine, Tanta University, Tanta, Egypt

\begin{abstract}
Background: Ischemic heart disease is considered the most common cause of death worldwide. Inflammation and oxidative stress play an important role in the pathogenesis of all phases of atherosclerosis and atherosclerotic plaque rupture which are the main mechanisms in the pathophysiology of acute ST-segment elevation myocardial infarction (STEMI). Monocyte to HDL ratio (MHR) was defined as a novel potential marker to determine inflammation and used to predict clinical outcome in patients with STEMI.
\end{abstract}

Objectives: To study the relation between monocyte to high-density lipoprotein cholesterol ratio and short-term outcome in patients with acute ST-segment elevation myocardial infarction undergoing primary percutaneous coronary intervention (PCI).

Methods: This study was conducted on a number of 100 patients diagnosed with STEMI and underwent primary PCI in Tanta University Hospitals, Cardiovascular Department, from June 2017 to December 2017. The primary end points were all cause mortality and major adverse cardiovascular events (MACE) including a composite of death, nonfatal reinfarction, target vessel re-vascularization, or new onset congestive heart failure during hospitalization and during the 3-months clinical follow-up.

Patients were divided into 3 tertiles according to the monocyte to high- density lipoprotein cholesterol ratio (MHR); Tertile 1: MHR $<10$ (number of patients $=41$ ). Tertile 2: MHR $10-20$ (number of patients $=36$ ). Tertile $3:$ MHR $>20$ (number of patients $=23$ ).

Results: Patients in the high MHR tertile showed significantly lower systolic blood pressure, higher Killip class IIIV, lower final angiographic TIMI flow, higher WBCs, neutrophils and monocytes count, higher serum LDL level and lower HDL levels, higher ejection fraction, higher all the composite endpoints of MACE including death, reinfarction and CHF. The study showed that MHR level $>12.3$ predicted the overall MACE following STEMI with a sensitivity and specificity above $75 \%$.

Correspondence to: Dr. Ahmed I. El-Shall, The Department of Cardiology, Faculty of Medicine, Tanta University, Tanta, Egypt
Conclusion: Monocyte to high-density lipoprotein cholesterol ratio is an independent prognostic factor for both inhospital adverse outcomes, as well as, short-term adverse outcomes among STEMI patients who underwent primary PCI.

Key Words: pPCI - Monocytes - STEMI - HDL.

\section{Introduction}

ATHEROSCLEROSIS and atherosclerotic plaque rupture are the main causes of ST-segment elevation myocardial infarction (STEMI). Inflammation plays a pivotal role in formation of atherosclerosis and may lead to plaque rupture in the presence of several risk factors [1].

Monocytes are essential immune system cells with unique roles during inflammatory response and contribute the pathophysiology of all stages of atherosclerosis [2].

The so-called good cholesterol, high density lipoprotein cholesterol (HDL-C) protects endothelial cells from inflammation and oxidative stress by several mechanisms. HDL promotes reverse cholesterol transport from the arterial wall, specifically from lipid-laden macrophages [3]

The balance between pro-inflammatory and anti-inflammatory mediators and its role in the development of atherosclerosis led to testing a novel biomarker (MHR) that represent this balance [4]

Our study aim was to study the relation between monocyte to high-density lipoprotein cholesterol ratio and short-term outcome in patients with acute STEMI undergoing primary PCI. 


\section{Patients and Methods}

This study was conducted on a number of 100 patients of both genders diagnosed with STEMI and underwent primary percutaneous coronary intervention in Tanta University Hospitals, cardiovascular department.

All patients were subjected to detailed history taking, full clinical examination, 12 lead electrocardiogram, echocardiography and primary PCI strategy. In all patients recruited in this study, blood samples were collected on admission before PCI from the ante-cubital vein by an atraumatic puncture and were sent to the laboratory for analysis of: Serum cardiac biomarkers, complete blood count (hemoglobin, hematocrite (Hct), total white blood cells (WBCs), neutrophils, lymphocytes, eosinophiles, basophiles, monocytes and platelets) and lipid profile (total cholesterol, high density lipoprotein cholesterol, low density lipoprotein cholesterol, triglycerides).

Monocyte to high density lipoprotein ratio was calculated by dividing monocyte count to HDL level from the same blood sample obtained before primary PCI.

The primary end points were all cause mortality and major adverse cardiovascular events (MACE) including a composite of death, nonfatal re-infarction, target vessel re-vascularization, or new onset congestive heart failure during hospitalization and during the 3-months clinical follow-up.

Patients were divided into 3 tertiles according to the monocyte to high-density lipoprotein cholesterol ratio (MHR); Tertile 1: MHR $<10$ (number of patients=41). Tertile 2: MHR 10-20 (number of patients=36). Tertile 3: MHR $>20$ (number of patients=23).

Exclusion criteria included patients with prior myocardial infarction, patients who previously underwent coronary artery bypass graft (CABG) or PCI, patients with end stage renal failure (creatinine clearance $<15 \mathrm{~mL} / \mathrm{min}$ ), patients with hematological disorders, patients with active hepatobiliary disease, patients with active infections, patients with neoplastic diseases, patients with recent major surgical procedure or trauma and patients with known dyslipidemia.

Patients in each group were matched to other groups regarding different demographic, clinical and laboratory parameters.
Duration of the study: This study was done in a period of six months from June 2017 to December 2017.

Statistical analysis: Data were fed to the computer and analyzed using IBM SPSS software package version 20.0. Qualitative data were described using number and percent. Quantitative data were described using range (minimum and maximum), mean, standard deviation and median. Significance of the obtained results was judged at the $5 \%$ level.

\section{Results}

Patient demographics: Regarding the gender: 75 patients $(75 \%)$ of the study population were males and 25 patients $(25 \%)$ were females; There was no statistically significant difference between the three groups $(p$-value $=0.398)$ and regarding the age: The age of the study population ranged from 30 to 85 years with a mean of $56.70 \pm 11.9$ years and there was no statistically significant difference between the three groups $(p$-value $=$ 0.070).

Prevalence of risk factors: Regarding Diabetes mellitus: 33 patients (33\%) of the study population were diabetic, and there was no statistically significant difference between the studied groups ( $p$ value $=0.224)$. Regarding systemic hypertension: 34 patients (34\%) of the study population were hypertensive. There was no statistically significant difference between the studied groups ( $p$-value $=$ 0.462). Regarding Smoking: 55 patients (55\%) of the study population were smokers. There was no statistically significant difference between the studied groups $(p$-value $=0.305)$ and regarding the family history of coronary artery disease: 9 patients (9\%) of the study population had positive family history of coronary artery disease and there was no statistically significant difference between the incidence of family history of coronary artery disease in the studied groups $(p$-value $=0.560)$ (Table 1).

Clinical presentation: Regarding the Systolic blood pressure; it ranged between 60.0 and 210.0 $\mathrm{mmHg}$ with a mean of $128.2 \pm 29.95 \mathrm{mmHg}$, there was a statistically significant difference between the three groups with patients in tertile 3 presenting with lower blood pressure ( $p$-value $=0.047$ ), Regarding the diastolic blood pressure; it ranged between 40.0 and $130.0 \mathrm{mmHg}$, with a mean of $79.70 \pm 17.20 \mathrm{mmHg}$. There was no statistically significant difference between the three groups $(p$ value $=0.236$ ) and regarding the heart rate; it ranged 
between 30 and 130 beats per minute (bpm) with a mean of $86.15 \pm 21.58$ and there was no statistically significant difference between the three groups ( $p$ value $=0.693)$ (Table 2).

Regarding Killip class: 79 patients (79\%) of the study population presented with Killip class I while 21 patients $(21 \%)$ presented with Killip class of II-IV, there was statistically significant difference between the studied groups with patients in tertile 3 presented with higher Killip class (II-IV) ( $p$ value $=0.038$ ) and regarding the STEMI location; 65 patients $(65 \%)$ of the study population presented with anterior STEMI, while 32 patients $(32 \%)$ presented with inferior STEMI and 3 patients (3\%) presented with lateral STEMI. There was no statistically significant difference between the three groups $(p$-value $=0.119)($ Table 3$)$.

\section{Laboratory parameters:}

$C B C$ : Regarding the haemoglobin level, it ranged from $10.0-18.0 \mathrm{gm} / \mathrm{dl}$, with a mean of $13.35 \pm$ 1.57 . There was no statistically significant difference between the studied groups $(p$-value $=0.095)$.

Regarding the White blood cells, it ranged from $4.60-33.80\left(\mathrm{x} 103 / \mathrm{mm}^{3}\right)$, with a mean of $12.75 \pm$ 4.86 , there was a statistically significant difference between the studied groups with the WBCs of the patients in tertile 3 were higher ( $p$-value $=<0.001$, the neutrophils ranged from 2.90-27.04 (x103/mm $)$ with a mean of $9.64 \pm 4.21$. There was a statistically significant difference between the studied groups with the neutrophils of patients in tertile 3 were higher $(p$-value $=0.433)$ and the monocytes ranged from $100.0-1500.0 / \mathrm{mm}^{3}$ with a mean of $573.1 \pm$ 274.3 , there was a statistically significant difference between the studied groups with the monocytes of tertile 3 were higher $(p$-value $=0<0.001)$.

Finally, regarding the platelets count ranged from $90.0-562.0\left(\mathrm{x} 103 / \mathrm{mm}^{3}\right)$ with a mean of 239.7 \pm 71.28 , There was no statistically significant difference between the studied groups $(p$-value $=$ 0.433) (Table 4).

Lipid profile: Regarding the high density lipoprotein (HDL), it ranged between $30.0-67.0 \mathrm{mg} / \mathrm{dl}$, with a mean of $41.27 \pm 7.84$, There was a statistically significant difference between the studied groups with patients in tertile 3 had lower HDL level ( $p$ value $=0.001$ ). Regarding the low density lipoprotein (LDL), it ranged between $69.0-230.0 \mathrm{mg} / \mathrm{dl}$ with a mean of $144.6 \pm 29.3$. There was a statistically significant difference between the studied groups with patients in tertile 3 had higher LDL level ( $p$ - value $=0.016$ ), and regarding the triglycerides, it ranged between $70.0-280.0 \mathrm{mg} / \mathrm{dl}$ with a mean of 151 , there was no statistically significant difference between the studied groups $(p$-value $=0.215)$ (Table $5)$.

Echocardiograhy: Regarding the ejection fraction, it ranged between 24.0-67.0\%, with a mean of $45.88 \pm 11.24$. There was a statistically significant difference between the studied groups with the patients in tertile 1 had lower ejection fraction ( $p$ value $=0.023$ ) (Table 6).

Angiographic findings: Regarding the number of diseased vessel: 49 patients (49\%) of the study population had a single vessel disease, and 51 patients $(51 \%)$ had a multi-vessels disease. There was no statistically significant difference between the studied groups $(p$-value $=0.197)$. Sixteen patients $(16 \%)$ of the study population had a final TIMI flow $<3$ and the rest of the patients $(84 \%)$ had a final TIMI III flow, there was statistically significant difference between the studied groups with more patients in tertile 3 had a final TIMI flow $<3$ $(p$-value $=<0.001)($ Table 7$)$.

In hospital major adverse cardiac events (MACE): Regarding death, 6 patients $(6 \%)$ of the study population died during the hospital stay either due to ventricular arrhythmia or cardiogenic shock. There was a statistically significant difference between the stu-died groups with the prevalence of in-hospital death increased from group one to group three ( $p$ - value $=0.001)$. Regarding re-infarction, none of the patients of the study population suffered from re-infarction during the hospital stay. Regarding congestive heart failure (CHF), 11 patients $(11 \%)$ in our study suffered from CHF during the hospital stay. There was a statistically significant difference between the studied groups with the prevalence of in-hospital CHF increased from group one to group three, $(p-$ value $<0.001)$ and regarding target vessel re-vascularization (TVR), none of the patients of the study population had TVR during the hospital stay (Table 8).

During the three months follow-up: Regarding death: 2 patients died (2\%), there was a statistically significant difference between the studied groups as death occurred during the 3 months follow-up in patients of tertile 3 only ( $p$-value $=0.039)$. Regarding re-infarction, 4 patients (4\%) suffered from reinfarction. There was a statistically significant difference between the studied groups with the incidence of re-infarction increased from group 
one to group three ( $p$-value $=0.012)$. Regarding congestive heart failure, 5 patients $(5 \%)$ suffered from CHF. There was a statistically significant difference between the studied groups with the prevalence of follow-up CHF increased from group one to group three $(p$-value $=0.012)$ and regarding target vessel revascularization, only one patient had TVR. There was no statistically significant difference between the groups $(p$-value $=0.197)$ (Table 8).

Overall, in-hospital and three months followup MACE occurred in 29 patients (29\%) in our study. In tertile 1,4 patients $(9.8 \%)$ suffered from MACE. In tertile 2,8 patients $(22.2 \%)$ suffered from MACE. In tertile 3, 17 patients $(73.9 \%)$ suffered from MACE. There was a statistically significant difference between the groups with the incidence of MACE increased from tertile 1 to tertile 3 ( $p$-value $<0.001)$ (Table 8$)$.
Univariate and multivariate analysis of MACE: Univariate and multivariate regression analyses were performed to investigate the possible predictors of overall in-hospital and follow-up MACE in the study population. In univariate regression analysis, Killip II-IV, final TIMI $<3$ flow, high WBCs count, high neutrophils count, high monocytes count, low HDL level, high MHR and high MHR tertiles were correlated with MACE. In the multivariate regression analysis, using model adjusted for aforementioned parameters, Killip IIIV, MHR tertile 2 and MHR tertile 3 independently predicted MACE (Table 9).

The receiver operating characteristic (ROC) analysis showing the performance and predictive accuracy of MHR in predicting MACE, the area under the curve (AUC) was $0.762(p<0.001)$, with cutoff value MHR more than $>12.4$, with $75.86 \%$ sensitivity and $75.86 \%$ specificity.

Table (1): Prevalence of risk factors in the study population.

\begin{tabular}{|c|c|c|c|c|c|c|c|c|c|c|}
\hline \multirow{3}{*}{ Risk factors } & \multirow{2}{*}{\multicolumn{2}{|c|}{$\begin{array}{c}\text { Total } \\
(\mathrm{n}=100)\end{array}$}} & \multicolumn{6}{|c|}{ MHR Tertile } & \multirow{3}{*}{$\mathrm{F}$} & \multirow{3}{*}{$p$-value } \\
\hline & & & \multicolumn{2}{|c|}{$\begin{array}{c}<10 \\
(\mathrm{n}=41)\end{array}$} & \multicolumn{2}{|c|}{$\begin{array}{l}10-20 \\
(\mathrm{n}=36)\end{array}$} & \multicolumn{2}{|c|}{$\begin{array}{c}>20 \\
(\mathrm{n}=23)\end{array}$} & & \\
\hline & No. & $\%$ & No. & $\%$ & No. & $\%$ & No. & $\%$ & & \\
\hline Diabetes & 33 & 33.0 & 12 & 29.3 & 10 & 27.8 & 11 & 47.8 & 2.989 & 0.224 \\
\hline Hypertension & 34 & 34.0 & 14 & 34.1 & 10 & 27.8 & 10 & 43.5 & 1.542 & 0.462 \\
\hline Smoking & 55 & 55.0 & 19 & 46.3 & 21 & 58.3 & 15 & 65.2 & 2.374 & 0.305 \\
\hline Family history & 9 & 9.0 & 4 & 9.8 & 2 & 5.8 & 3 & 13 & 1.148 & 0.560 \\
\hline
\end{tabular}

Table (2): Comparison between the different studied groups according to clinical presentation.

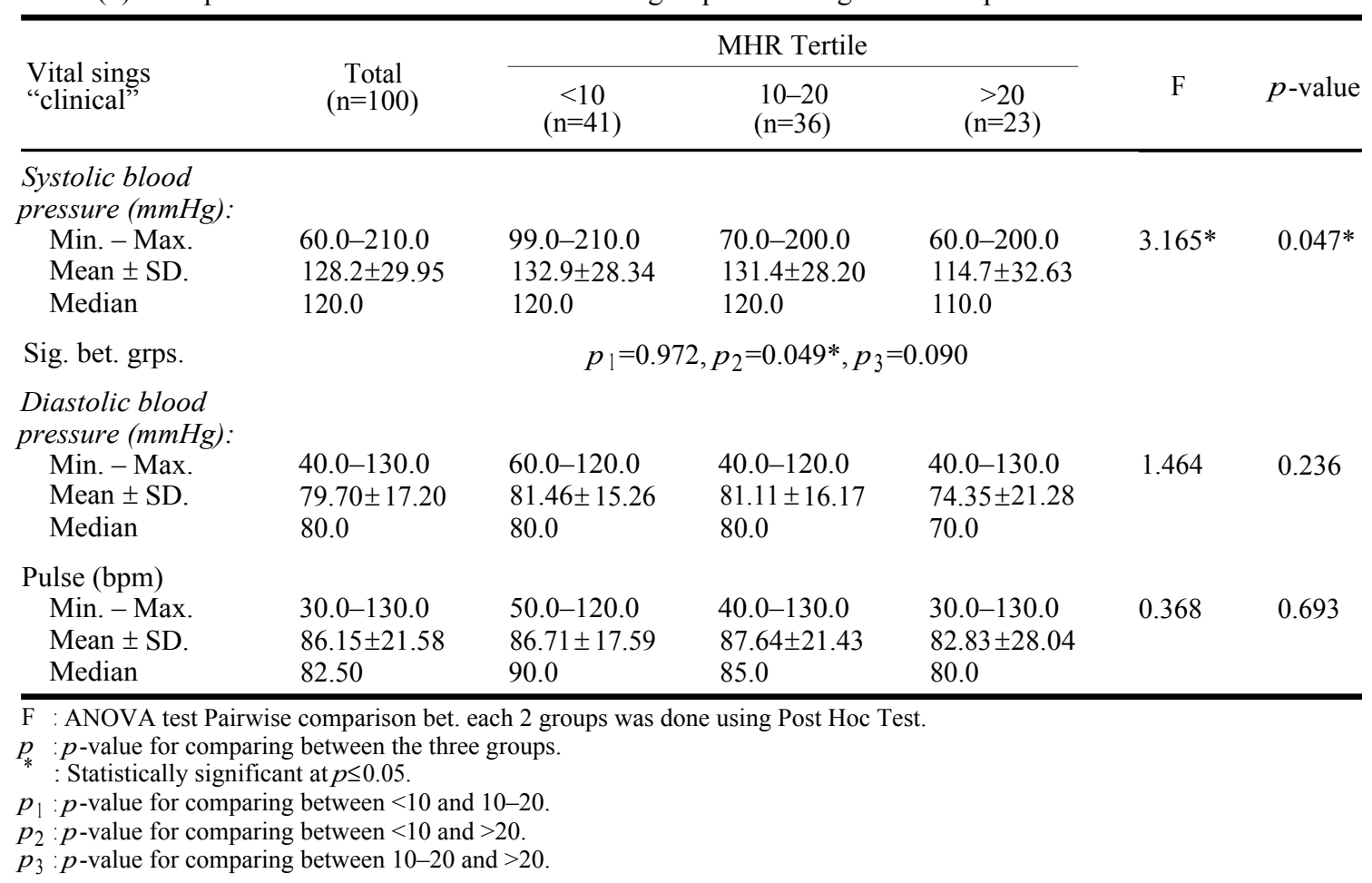


Table (3): Comparison between the different studied groups according to different parameters.

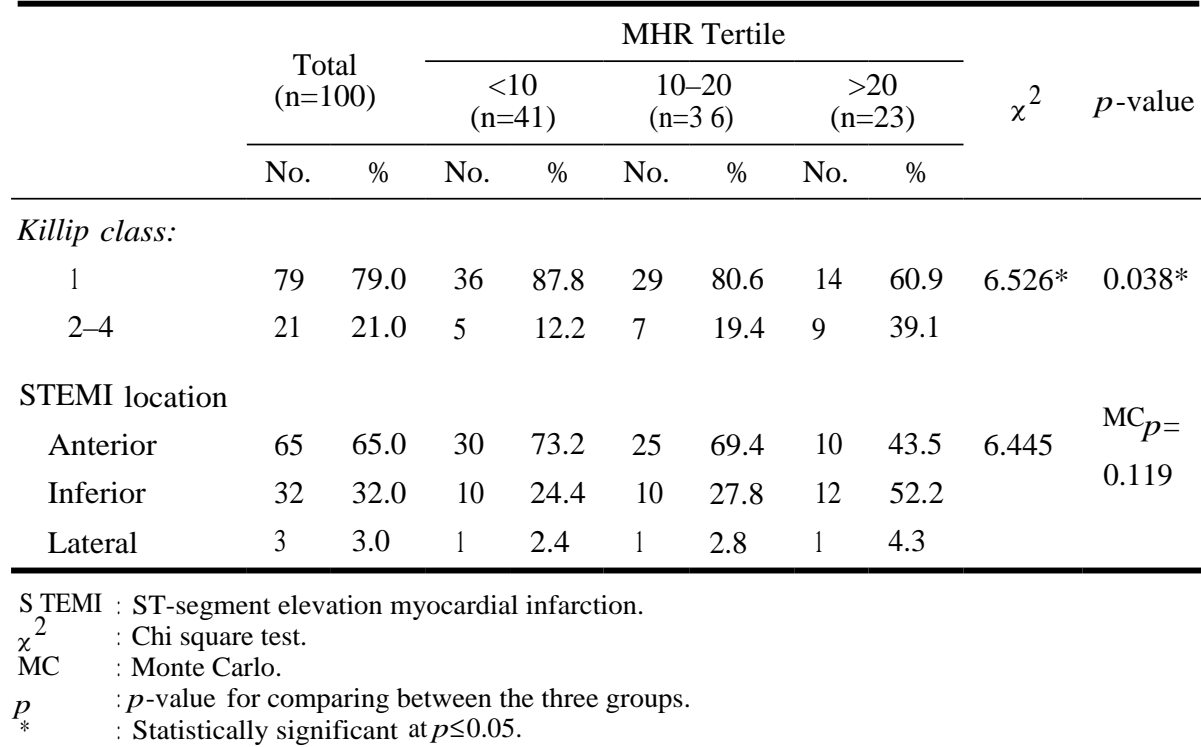

Table (4): Complete blood count parameters in the study population.

\begin{tabular}{|c|c|c|c|c|c|c|}
\hline \multirow[b]{2}{*}{$\mathrm{CBC}$} & \multirow[b]{2}{*}{$\begin{array}{c}\text { Total } \\
(\mathrm{n}=100)\end{array}$} & \multicolumn{3}{|c|}{ MHR Tertile } & \multirow[b]{2}{*}{ Test of Sig. } & \multirow[b]{2}{*}{$p$-value } \\
\hline & & $\begin{array}{c}<10 \\
(\mathrm{n}=41)\end{array}$ & $\begin{array}{l}10-20 \\
(\mathrm{n}=36)\end{array}$ & $\begin{array}{c}>20 \\
(\mathrm{n}=23)\end{array}$ & & \\
\hline \multicolumn{7}{|c|}{ Hemoglobin $(\mathrm{gm} / \mathrm{dl})$ : } \\
\hline Min.-Max. & $10.0-18.0$ & $11.0-16.0$ & $10.0-18.0$ & $10.0-16.0$ & & \multirow[t]{3}{*}{0.095} \\
\hline Mean \pm SD & $13.35 \pm 1.57$ & $12.99 \pm 1.33$ & $13.41 \pm 1.75$ & $13.87 \pm 1.58$ & 2.412 & \\
\hline Median & 13.0 & 13.0 & 13.0 & 1.5 & & \\
\hline \multicolumn{7}{|c|}{$\begin{array}{l}\text { White Bloogd Cells } \\
(\times 10 \mathrm{~mm}):\end{array}$} \\
\hline Min.-Max. & $4.60-33.80$ & $5.20-22.20$ & $4.60-19.60$ & $8.20-33.80$ & & \multirow[t]{3}{*}{$<0.001 *$} \\
\hline Mean \pm SD. & $12.75 \pm 4.86$ & $10.30 \pm 3.32$ & $12.92 \pm 3.74$ & $16.85 \pm 5.93$ & $27.449 *$ & \\
\hline Median & 11.65 & 10.0 & 12.25 & 15.80 & & \\
\hline Sig. bet. grps. & \multicolumn{6}{|c|}{$p_{1}=0.002^{*}, p_{2}<0.001 *, p_{3}=0.021^{*}$} \\
\hline \multicolumn{7}{|l|}{$\begin{array}{l}\text { Platęlets } \\
\left(\times 10 \% \mathrm{~mm}^{3}\right):\end{array}$} \\
\hline Min.-Max. & $90.0-562.0$ & $108.0-331.0$ & $90.0-562.0$ & $165.0-370.0$ & & \multirow[t]{3}{*}{0.433} \\
\hline Mean \pm SD. & $239.7 \pm 71.28$ & $231.6 \pm 50.94$ & $241.0 \pm 94.16$ & $252.4 \pm 61.21$ & 1.674 & \\
\hline Median & 230.0 & 224.0 & 227.5 & 244.0 & & \\
\hline \multicolumn{7}{|l|}{$\begin{array}{l}\text { Neutḩophilss } \\
(x 10 \mathrm{~mm})\end{array}$} \\
\hline Min.-Max. & $2.90-27.04$ & $3.30-18.90$ & $2.90-16.10$ & $5.50-27.04$ & & \multirow[t]{3}{*}{$<0.001 *$} \\
\hline Mean $\pm \mathrm{SD}$ & $9.64 \pm 4.21$ & $7.81 \pm 3.19$ & $9.80 \pm 3.42$ & $12.67 \pm 5.16$ & $19.665^{*}$ & \\
\hline Median & 9.0 & 7.40 & 9.25 & 11.40 & & \\
\hline Sig. bet. grps. & \multicolumn{6}{|c|}{$p_{1}=0.010^{*}, p_{2}<0.001 *, p_{\underline{3}}=0.042^{*}$} \\
\hline \multirow{4}{*}{$\begin{array}{l}\text { Monocytes } \\
\left({\left.\text { number } / m^{3}\right)}^{3}\right) \\
\text { Min.-Max. } \\
\text { Mean } \pm \text { SD. } \\
\text { Median }\end{array}$} & & & & & & \multirow{4}{*}{$<0.001 *$} \\
\hline & $100.0-1500.0$ & $100.0-820.0$ & $324.0-900.0$ & $615.0-1500.0$ & & \\
\hline & $573.1 \pm 274.3$ & $360.0 \pm 133.6$ & $592.6 \pm 159.4$ & $922.3 \pm 230.1$ & $64.243^{*}$ & \\
\hline & 510.0 & 336.0 & 590.0 & 878.0 & & \\
\hline Sig. bet. grps. & \multicolumn{6}{|c|}{$p_{1}=0.001^{*}, p_{2}<0.01^{*}, p_{\underline{3}}<0.001^{*}$} \\
\hline \multicolumn{3}{|c|}{$\begin{array}{l}\text { F: ANOVA test. } \\
\text { H: Kruskal Wallis test. } \\
\text { - Pairwise comparison bet. each } 2 \text { groups was done using } \\
\text { Post Hoc Test (Dunn's for multiple comparisons test). }\end{array}$} & \multicolumn{4}{|c|}{$\begin{array}{l}p: p \text {-value for comparing between the three groups. } \\
*: \text { Statistically significant at } p \leq 0.05 \\
p 1: p \text {-value for comparing between }<10 \text { and } 10-20 \\
p 2: p \text {-value for comparing between }<10 \text { and }>20 \\
p 3: p \text {-value for comparing between } 10-20 \text { and }>20\end{array}$} \\
\hline
\end{tabular}


Table (5): Lipid profile in the study population.

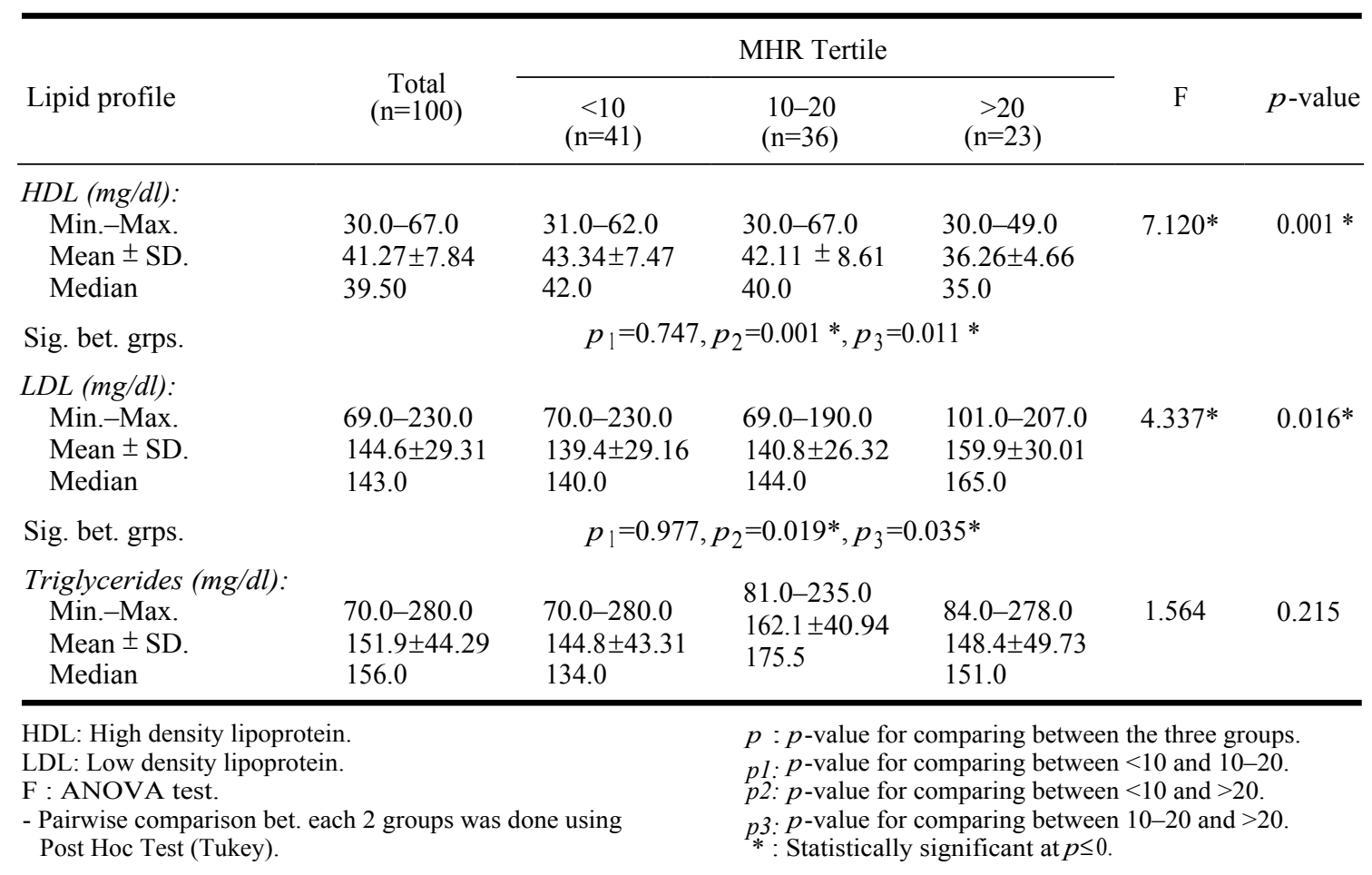

Table (6): Ejection fraction in the study population.

\begin{tabular}{|c|c|c|c|c|c|c|}
\hline & \multirow{2}{*}{$\begin{array}{c}\text { Total } \\
(\mathrm{n}=100)\end{array}$} & \multicolumn{3}{|c|}{ MHR Tertile } & \multirow[b]{2}{*}{$\mathrm{F}$} & \multirow[b]{2}{*}{$p$-value } \\
\hline & & $\begin{array}{c}<10 \\
(\mathrm{n}=41)\end{array}$ & $\begin{array}{c}10-20 \\
(n=36)\end{array}$ & $\begin{array}{c}>20 \\
(\mathrm{n}=23)\end{array}$ & & \\
\hline $\begin{array}{l}\text { Ejection fraction } \\
\text { Min.-Max. } \\
\text { Mean } \pm \text { SD. } \\
\text { Median }\end{array}$ & $\begin{array}{l}24.0-67.0 \\
45.88 \pm 11.24 \\
44.0\end{array}$ & $\begin{array}{l}25.0-67.0 \\
44.22 \pm 11.04 \\
41.0\end{array}$ & $\begin{array}{l}24.0-66.0 \\
44.19 \pm 11.11 \\
43.0\end{array}$ & $\begin{array}{l}34.0-66.0 \\
51.48 \pm 10.40 \\
49.0\end{array}$ & $3.923 *$ & $0.023 *$ \\
\hline Sig. bet. grps. & \multicolumn{6}{|c|}{$p_{1}=0.972, p_{\underline{2}}=0.049^{*}, p_{\underline{3}}=0.090$} \\
\hline $\begin{array}{l}\text { F: ANOVA test. } \\
=\text { Pairwise compari } \\
\text { Post Hoc Test (Tu } \\
p: p \text {-value for com }\end{array}$ & $\begin{array}{l}\text { ch } 2 \text { groups was } \\
\text { jeen the three } \mathrm{g}\end{array}$ & ne using & \multicolumn{4}{|c|}{$\begin{array}{l}p 1: p \text {-value for comparing between }<10 \text { and } 10-20 \text {. } \\
\text { p2: } p \text {-value for comparing between }<10 \text { and }>20 \text {. } \\
p_{*} 3: \text {-value for comparing between } 10-20 \text { and }>20 \text {. }\end{array}$} \\
\hline
\end{tabular}

Table (7): Angiographic findings in the study population.

\begin{tabular}{|c|c|c|c|c|c|c|c|c|c|c|}
\hline & \multirow{2}{*}{\multicolumn{2}{|c|}{$\begin{array}{c}\text { Total } \\
(\mathrm{n}=100)\end{array}$}} & \multicolumn{6}{|c|}{ MHR Tertile } & \multirow{3}{*}{$\chi^{2}$} & \multirow{3}{*}{$p$-value } \\
\hline & & & \multicolumn{2}{|c|}{$\begin{array}{c}<10 \\
(\mathrm{n}=41)\end{array}$} & \multicolumn{2}{|c|}{$\begin{array}{l}10-20 \\
(\mathrm{n}=36)\end{array}$} & \multicolumn{2}{|c|}{$\begin{array}{c}>20 \\
(\mathrm{n}=23)\end{array}$} & & \\
\hline & No. & $\%$ & No. & $\%$ & No. & $\%$ & No. & $\%$ & & \\
\hline \multicolumn{11}{|c|}{ Number ofdiseased vessels: } \\
\hline Single vessel & 49 & 49.0 & 20 & 48.8 & 19 & 52.8 & 10 & 43.5 & 0.487 & 0.784 \\
\hline Multi vessel & 51 & 51.0 & 21 & 51.2 & 17 & 47.2 & 13 & 56.5 & & \\
\hline \multicolumn{11}{|l|}{ Final TIMI flow: } \\
\hline$<3$ & 16 & 16.0 & 2 & 4.9 & 4 & 11.1 & 10 & 43.5 & $17.335^{*}$ & $<0.001 *$ \\
\hline 3 & 84 & 84.0 & 39 & 95.1 & 32 & 88.9 & 13 & 56.5 & & \\
\hline
\end{tabular}


Table (8): Prevalence of major adverse cardiac outcomes in the study population.

In-hospital death In-hospital reinfarction In-hospital CHF In-hospital TVR

3 months follow-up death 3 months follow-up reinfarction 3 months follow-up CHF 3 months follow-up TVR MACE

CHF: Congestive heart failure. TVR: Target vessel revascularization $x^{2}$ : Chi square test

\begin{tabular}{|c|c|c|c|c|c|c|c|c|c|}
\hline \multirow{2}{*}{\multicolumn{2}{|c|}{$\begin{array}{c}\text { Total } \\
(\mathrm{n}=100)\end{array}$}} & \multicolumn{6}{|c|}{ MHR Tertile } & \multirow{3}{*}{$x^{2}$} & \multirow{3}{*}{$p$-value } \\
\hline & & \multicolumn{2}{|c|}{$\begin{array}{c}<10 \\
(\mathrm{n}=41)\end{array}$} & \multicolumn{2}{|c|}{$\begin{array}{c}10-20 \\
(\mathrm{n}=36)\end{array}$} & \multicolumn{2}{|c|}{$\begin{array}{c}>20 \\
(\mathrm{n}=23)\end{array}$} & & \\
\hline No. & $\%$ & No. & $\%$ & No. & $\%$ & No. & $\%$ & & \\
\hline 6 & 6.0 & 1 & 2.4 & 1 & 2.8 & 4 & 17.4 & $10.031 *$ & $\mathrm{MC}_{p}=0.001 *$ \\
\hline 0 & 0.0 & 0 & 0.0 & 0 & 0.0 & 0 & 0.0 & & - \\
\hline 11 & 11 & 1 & 2.4 & 5 & 13.9 & 5 & 21.8 & $16.552^{*}$ & $<0.001 *$ \\
\hline 0 & 0.0 & 0 & 0.0 & 0 & 0.0 & 0 & 0.0 & & \\
\hline 2 & 2.1 & 0 & 0.0 & 0 & 0.0 & 2 & 8.7 & $4.953^{*}$ & $\mathrm{MC}_{p}=0.039 *$ \\
\hline 4 & 4.3 & 1 & 0.0 & 1 & 2.9 & 2 & 8.7 & $6.451 *$ & $\mathrm{MC}_{p}=0.012^{*}$ \\
\hline 5 & 5 & 1 & 2.4 & 1 & 2.7 & 3 & 13.0 & $19.094 *$ & $<0.001 *$ \\
\hline 1 & 1.1 & 0 & 0.0 & 0 & 0.0 & 1 & 4.3 & 3.122 & $\mathrm{MC}_{p}=0.197$ \\
\hline 29 & 29.0 & 4 & 9.8 & 8 & 22.2 & 17 & 73.9 & $30.710^{*}$ & $<0.001 *$ \\
\hline
\end{tabular}

Table (9): Univariate and multivariate analysis of major adverse cardiac outcomes in the study population.

Univariate

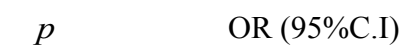

Killip class (2-4)

Final TIMI flow $(<3)$

White blood cells $\left(\mathrm{x}_{3} 0_{3}^{3} / \mathrm{mm}^{3}\right)$

Neutrophils (x1 $0 / \mathrm{mm}^{3}$ )

Monocytes (number/mm3)

HDL (mg/dl)

Monocytes-HDL ratio (MHR)

MHR Tertile:

$$
\begin{aligned}
& <10 \\
& 10-20 \\
& >20
\end{aligned}
$$

HDL : High density lipoprotein.

\begin{tabular}{|c|c|c|c|}
\hline \multicolumn{2}{|c|}{ Univariate } & \multicolumn{2}{|c|}{ \#Multivariate } \\
\hline$p$ & OR (95\%C.I) & $p$ & OR (95\%C.I) \\
\hline $\begin{array}{l}<0.001 * \\
0.003 * \\
0.001 * \\
0.001 * \\
0.001 * \\
0.001 * \\
<0.001 *\end{array}$ & $\begin{array}{l}16.246(5.06-52.19) \\
5.702(1.84-17.72) \\
1.216(1.082-1.367) \\
1.255(1.103-1.429) \\
1.003(1.0-1.01) \\
0.871(0.80-0.95) \\
1.178(1.09-1.27)\end{array}$ & $\begin{array}{l}<0.001 * \\
0.623 \\
0.853 \\
0.406 \\
0.401 \\
0.278 \\
0.297\end{array}$ & $\begin{array}{l}20.993(4.18-105.33) \\
0.643(0.11-3.76) \\
1.011(0.90-1.14) \\
1.110(0.87-1.42) \\
1.007(0.99-1.02) \\
0.870(0.68-1.12) \\
0.696(0.35-1.37)\end{array}$ \\
\hline $\begin{array}{l}0.001 * \\
0.265 \\
<0.001 *\end{array}$ & $\begin{array}{l}0.147(0.05-0.47) \\
0.585(0.228-1.502) \\
15.347(5.03-46.85)\end{array}$ & $\begin{array}{l}0.015^{*} \\
0.014^{*}\end{array}$ & $\begin{array}{l}0.015(0.0-4.4) \\
0.037(0.0-0.51)\end{array}$ \\
\hline
\end{tabular}
OR. : Odd's ratio.

C.I : Confidence interval.

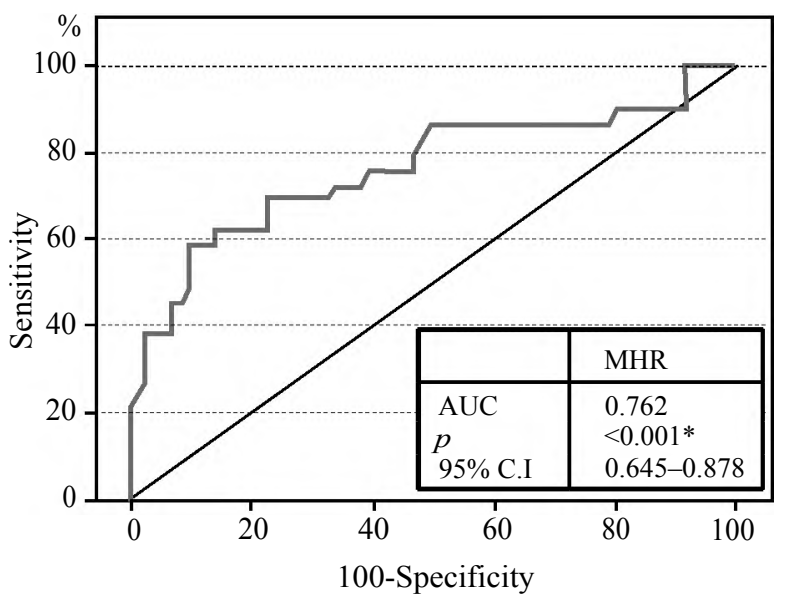

ROC curve for MHR to predict MACE. AUC: Area Under a Curve $p$-value: Probability value. CI: Confidence Intervals

$$
\text { Cut off Sensitivity Specificity PPV NPV }
$$$$
\begin{array}{lllll}
\text { MHR }>12.4 & 75.86 & 60.56 & 44.0 & 86.0
\end{array}
$$

PPV: Positive predictive value. NPV: Negative predictive value

\section{Discussion}

Inflammation and oxidative stress play an important role in the pathogenesis of all phases of atherosclerosis and atherosclerotic plaque rupture which are the main mechanisms in the pathophysiology of acute ST-segment elevation myocardial infarction (STEMI) [5]

The important role of inflammation has focused attention on the immune system. Development of atherosclerosis and its several complications are influenced by innate and adaptive immune responses [6].

Mononuclear leucocytes like macrophages and monocytes are the most crucial cell types for secretion of pro-inflammatory cytokines which lead to development and exacerbation of atherosclerosis [7]. In contrast, high density lipoprotein cholesterol 
(HDL-C) was shown to have anti-inflammatory, anti-oxidant, and anti-thrombotic effects [8].

Monocyte to HDL ratio (MHR) was defined as a novel potential marker to determine inflammation and used to predict clinical outcome in a few trials. The first study that indicated the relation between increased value of MHR and adverse cardiovascular outcomes was conducted by Kanbay et al., [4] in chronic kidney disease patients. After that, increased MHR was found to be predictor of AF recurrence after cryoballoon-based catheter ablation in another study [9] then, the value MHR has been revealed in various cardiovascular conditions especially in patients with STEMI; relating it to noreflow phenomenon, coronary slow flow, prognosis and mortality [10-12].

Our study aim was to study the relation between monocyte to high-density lipoprotein cholesterol ratio and short term outcome in patients with acute STEMI undergoing primary PCI.

The study sample was divided into three tertiles according to MHR; Tertile1 included 41 patients with low MHR $<10$, tertile 2 with 36 patients having MHR of 10-20 and tertile 3 which included 23 patients with high MHR of $>20$ and patients in each group were matched to other groups regarding different demographic, clinical and laboratory parameters.

Patients in the high MHR tertile showed significantly lower systolic blood pressure, higher Killip class II-IV, lower final angiographic TIMI flow, higher WBCs, neutrophils and monocytes count, higher serum LDL level and lower HDL levels and higher ejection fraction.

Other parameters that didn't show statically significant difference between the three tertiles include age, sex, family history of coronary artery disease, history of hypertension, diabetes or smoking, diastolic blood pressure and pulse on admission, STEMI location, number of diseased vessels, hemoglobin level, platelets count, serum triglycerides level.

In our study, our study also showed that high MHR was significantly associated with all the composite endpoints of MACE including death, reinfarction and CHF.

Similarly, Çiçek G et al., [12] in their study concluded that admission MHR is associated independently and significantly with short-term and long-term mortality in STEMI patients who undergo successful primary PCI. In addition to the that study, further evidence about the prognostic factor of MHR was supported by the study conducted by Açıkgöz SK et al., [13] which found that MHR was an independent predictor of in-hospital and 5 years mortality and MACE. Also, the prognostic value of MHR was demonstrated in patients with acute coronary syndrome (ACS) in the study conducted by Cetin MS et al., [14] which concluded that MHR was an independent predictor of severity of coronary artery disease and future cardiovascular events in patients with ACS.

Based on all of the above data and the results of our study, It's important to emphasize that the inflammatory biomarkers are becoming more and more important in predicting adverse outcomes after STEMI, especially when combined with a marker with an anti-inflammatory effect as HDL whose low levels itself has been shown to be associated with increased coronary risk. Our study showed that a MHR level > 12.3 predicted the overall MACE following STEMI with a sensitivity and specificity above $75 \%$.

\section{Limitations of the study:}

The study had some limitations. This is a singlecenter experience and represents a limited number of patients.

The follow-up period was only 3 months; longer follow-up periods may show different results.

Patients weren't administered new-generation antiplatelet agents such as prasugrel and ticagrelor.

Drug eluting stents (DES) weren't commonly used in the studied patients.

\section{Conclusion:}

Monocyte to high-density lipoprotein cholesterol ratio is an independent prognostic factor for both in-hospital adverse outcomes, as well as, short-term adverse outcomes among STEMI patients who underwent primary PCI.

\section{References}

1- DAVIES M.J.: A macro and micro view of coronary vascular insult in ischemic heart disease. Circulation. Sep., 82 (3 Suppl): II38-46, 1990.

2- RAVEENDRAN V.V., TAN X., SWEENEY M.E., LEVANT B., SLUSSER J., STECHSCHULTE D.J., et al.: Lipopolysaccharide induces $\mathrm{H} 1$ receptor expression and enhances histamine responsiveness in human coronary artery endothelial cells. Immunology. Apr., 132 (4): 57888, 2011.

3- COCKERILL G.W, RYE K.A., GAMBLE J.R., VADAS M.A. and BARTER P.J.: High-density lipoproteins inhibit cytokine-induced expression of endothelial cell adhesion 
molecules. Arterioscler Thromb Vasc Biol., Nov., 15 (11) 1987-94, 1995.

4- KANBAY M., SOLAK Y., UNAL H.U., KURT YG., GOK M., CETINKAYA H., et al.: Monocyte count/HDL cholesterol ratio and cardiovascular events in patients with chronic kidney disease. Int. Urol. Nephrol. Aug., 46 (8): 1619-25, 2014

5- LIBBY P.: Inflammation in atherosclerosis. Nature. Dec., 420 (6917): 868-74, 2002.

6- HANSSON G.K., LIBBY P., SCHONBECK U. and YAN $\mathrm{Z}-\mathrm{Q}$.: Innate and adaptive immunity in the pathogenesis of atherosclerosis. Circ. Res. Aug., 91 (4): 281-91, 2002.

7- CAMPOS T.M., PASSOS S.T., NOVAIS F.O., BEITING D.P., COSTA R.S., QUEIROZ A., et al.: Matrix metalloproteinase 9 production by monocytes is enhanced by TNF and participates in the pathology of human cutaneous Leishmaniasis. PLoS Negl. Trop. Dis., 8 (11): e3282, 2014.

8- KARABACAK M., KAHRAMAN F., SERT M., CELIK E., ADALI M.K. and VAROL E.: Increased plasma monocyte chemoattractant protein-1 levels in patients with isolated low high-density lipoprotein cholesterol. Scand J. Clin. Lab. Invest. Jul., 75 (4): 327-32, 2015.

9- CANPOLAT U., AYTEMIR K., YORGUN H., SAHINER L., KAYA E.B., CAY S., et al.: The role of preprocedural monocyte-to-high-density lipoprotein ratio in prediction of atrial fibrillation recurrence after cryoballoon-based catheter ablation. Eur pacing, arrhythmias, Card Electrophysiol J. Work groups Card pacing, arrhythmias, Card Cell. Electrophysiol. Eur. Soc. Cardiol. Dec., 17 (12): 1807-15, 2015.
10-BALTA S., CELIK T., OZTURK C., KAYA M.G., APARCI M., YILDIRIM A.O., et al.: The relation between monocyte to HDL ratio and no-reflow phenomenon in the patients with acute ST-segment elevation myocardial infarction. Am. J. Emerg. Med. [Internet]. Aug., [cited 2017 Jan 25], 34 (8): 1542-7. Available from: http://linkinghub.elsevier. com/retrieve/pii/S0735675 716301401, 2016.

11- CANPOLAT U., CETIN E.H., CETIN S., AYDIN S., AKBOGA M.K., YAYLA C., et al.: Association of Monocyte-to-HDL Cholesterol Ratio with Slow Coronary Flow is Linked to Systemic Inflammation. Clin. Appl. Thromb. Hemost. Jul., 22 (5): 476-82, 2016.

12- ÇIÇEK G., KUNDI H., BOZBAY M., YAYLA C. and UYAREL H.: The relationship between admission monocyte HDL-C ratio with short-term and long-term mortality among STEMI patients treated with successful primary PCI. Coron Artery Dis. [Internet]. May, [cited 2017 Jan., 25], 27 (3): 176-84. Available from: http://content. . wkhealth.com/linkback/openurl?sid =WKPTLP: landingpage\&an=00019501-201605000-00004, 2016.

13- ACIKGOZ S.K., ACIKGOZ E., SENSOY B., TOPAL S. and AYDOGDU S.: Monocyte to high-density lipoprotein cholesterol ratio is predictive of in-hospital and five-year mortality in ST-segment elevation myocardial infarction. Cardiol. J. 23 (5): 505-12, 2016.

14- CETIN M.S., OZCAN CETIN E.H., KALENDER E., AYDIN S., TOPALOGLU S., KISACIK H.L., et al. Monocyte to HDL Cholesterol Ratio Predicts Coronary Artery Disease Severity and Future Major Cardiovascular Adverse Events in Acute Coronary Syndrome. Heart Lung Circ. Nov., 25 (11): 1077-86, 2016. 


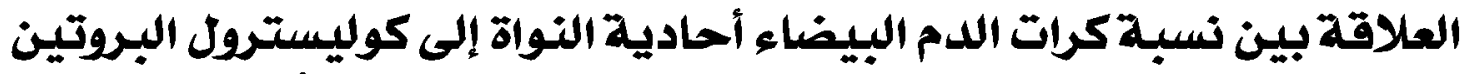

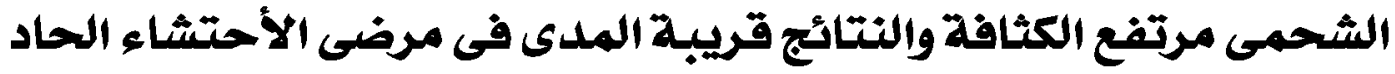

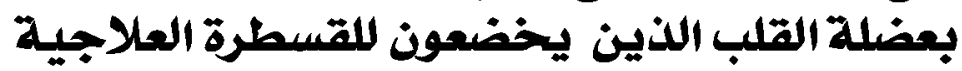

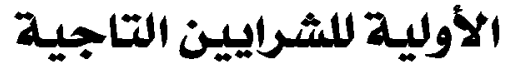

أجريت هذه الدراسة على مائة مريض أصيب بأحتثاء عضلة القلب وتمت المعالجة عن طريق القسطرة العلاجية الأولية على الشرايين التاجية

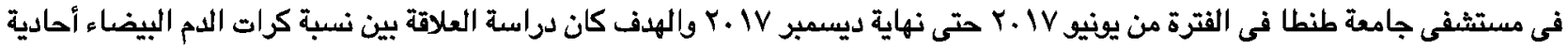
النواة إلى كوليسترول البروتينات الشحمية مرتفعة الكثافة والنتائج قريبة المدى لمرضى أحتشاء عضلة القلب الذين التين يخضعون القسطرة العلاجية الأولية الشرايين التاجية.

تم تقسيم المرضى إلى ثلاث مجموعات طبقاً لنسبة كراث كرات الام البيضاء أحادية النواة إلى كوليسترول البروتينات الشحمية مرتفعة الكثافة:

$$
\begin{aligned}
& \text { الجمموعة الأولى كانت النسبة أقل من ـ1. } \\
& \text { المجموعة الثانية كانت النسبة من •إلى .r. } \\
& \text { المجموعة الثائة كانت النسبة أكثر من .ب. كن. }
\end{aligned}
$$

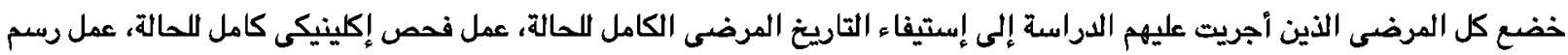

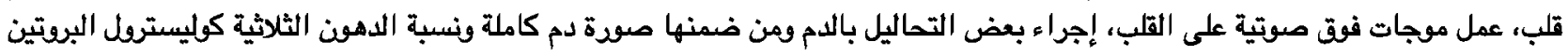

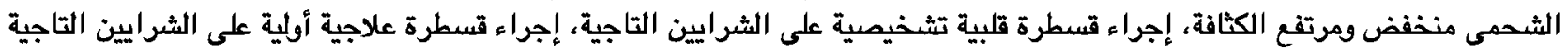
ومتابعة المريض أثناء تواجده بالمستشفى وأثناء الثخلاثة أشهر بعد خروجه منها.

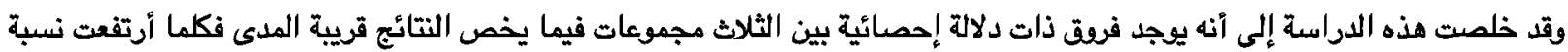

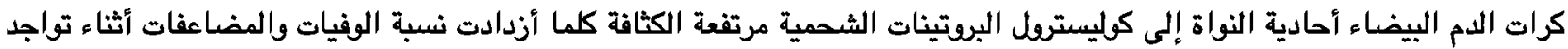
المرضى بالمستشفى وأيضاً فى خلال فترة ثلاثة المتابعة بعد حدوث البناء الجلطة.

كما خلصت الدراسة أنه المرضى بالمجموعة الثالثة صاحبة النسبة الأعلى من نسبة كرات الدم البيضاء أحادية النواة إلى كوليستريل

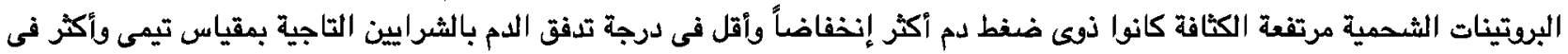

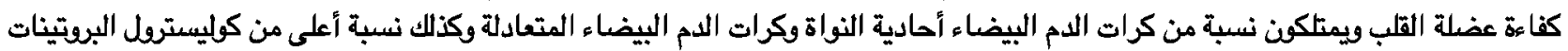

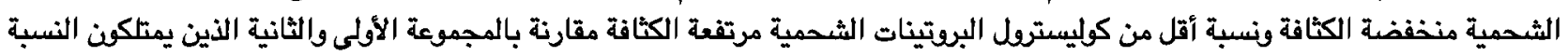
الأقل من كرات الدم البيضاء أحادية النواة إلى كوليسترول البروتينات البرتينات الثحمية مرتفعة الكثافة.

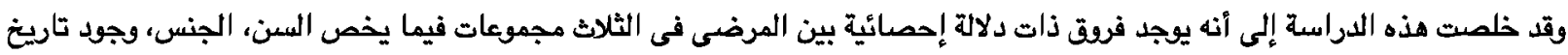

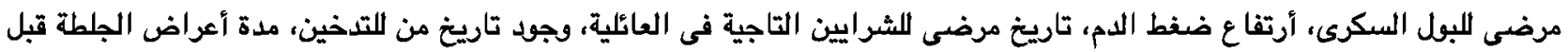

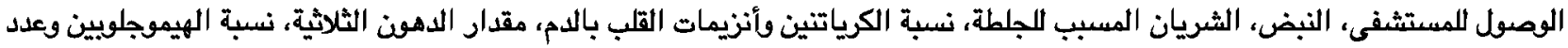
صفائع الدم. 